\title{
The knowledge and perceptions of history students of South Africa's Truth and Reconciliation Commission (TRC)
}

M OELOFSE AND A OOSTHUYSEN*

\begin{abstract}
Using the Truth and Reconciliation Commission of South Africa (TRC) and the concept of reconciliation as a case study, the article attempts to assess the knowledge and understanding of the registered undergraduate history students at the University of the Free State's main campus about the TRC and the concept and process of reconciliation in the country at large. The research will firstly assess whether the younger generation of students, specifically students taking history as a subject, have any knowledge of such a significant and contemporary event in South African historiography as the TRC process. Secondly, in relation to the aims and recommendations of the TRC and against the background of reconciliation efforts in the country, to perceive the views and thoughts of undergraduate history students on the progress in reconciliation endeavours in South Africa. As a result, a sample of 128 undergraduate history students was randomly selected to complete a quantitative questionnaire. The questionnaire consisted of both closed and open-ended questions. Group interviews, as a qualitative research method, were added and used to conduct interviews with 16 undergraduate history students selected randomly and answers were recorded. Accordingly, an explanatory mixedmethod research method approach was employed by implementing both the qualitative and quantitative method.
\end{abstract}

Key words: Truth and Reconciliation Commission of South Africa (TRC); reconciliation; views and perceptions; University of the Free State (UFS) main campus; undergraduate history students

\section{Introduction}

Nineteen years have passed since the "Promotion of National Unity and Reconciliation Act" (Act no. 34 of 1995) mandated the Truth and Reconciliation Commission of South Africa (TRC). The main goal of the TRC was to uncover the origins, nature and level of the gross human rights violations that took place in South Africa from 1 March 1960 to 10 May 1994, with the additional aim of fostering individual and national reconciliation. ${ }^{1}$ Emphasis has been placed on reconciliation in South Africa; however, taking into account the efforts and

University of the Free State, Department of History, PO Box 339, Bloemfontein 9300. Corresponding author email: oelofsem@ufs.ac.za; annelo911@gmail.com.

Republic of South Africa, "Promotion of National Unity and Reconciliation Act no. 34" in Government Gazette 361(16579), 1995, pp. 1-48.

TD The Journal for Transdisciplinary Research in Southern Africa, 10(1) July 2014, pp. 253-272. 
recommendations of the TRC there is intense debate whether South Africa has, in actual fact, made any progress in terms of reconciliation. ${ }^{2}$

Understanding history and having knowledge of historical events adds to a more balanced view of events. Therefore, it is essential to know the history of one's country and its citizens to value certain circumstances and/or interpersonal relations better. Whereas the TRC was a significant contemporary event in the history of South Africa, the concept of reconciliation is often used and debated in South Africa thus giving rise to certain questions such as: What is the level of knowledge and perception of registered undergraduate history students regarding South Africa's TRC and reconciliation? Would undergraduate history students have adequate knowledge about the TRC which happened only a few years ago and forms part of contemporary South African historiography? And: Although reconciliation as a concept is used so often, especially at the UFS, what would students' views be towards reconciliation in South Africa?

The TRC process took place when the said undergraduate students had already been born, thus adding to the contemporary nature of the TRC as an historical event for these students. Apart from this occurrence, as students at the UFS, they are exposed to a diverse multicultural and multiracial student population. Using the TRC and the concept of reconciliation as a case study, the article attempts to assess the knowledge and understanding of the registered undergraduate history students at the UFS main campus about the South African Truth and Reconciliation Commission (TRC), and the concept and process of reconciliation in the country at large.

It is against this background of the established TRC, where the aim was to set in motion a process of further reconciliation in the country, but also specifically at the UFS under the Rectorship of Professor Jonathan Jansen, that it was reasoned necessary to assess the knowledge and personal opinions of specifically history undergraduate students on the TRC and on reconciliation. It is important to note that in order to delimit the field of research no in-depth investigation was done about post-graduate and other students' insights regarding the field of study at other campuses of the UFS and/or at other universities. Consequently, it is not a comparative study to former research efforts undertaken on these issues. For this reason the research does not aim to generalise and/or compare the answers received from the students who participated in the research, or to provide in-depth answers and conclusions to the results. This research aims rather to stimulate further research and debate into these related topics. Furthermore, this research may contribute to more information and a greater awareness of the UFS history students' present-day knowledge, opinions and challenges of reconciliation, or the lack thereof, in a divided society.

\section{Historical background to the TRC}

South Africa, like other countries, has been confronted with a past withered by gross human rights violations. In 1994 the newly elected South African government was challenged with the question of how to deal with the atrocities of the past. The idea of a truth commission for South Africa originated with the African National Congress (ANC). With a truth commission, the emphasis can be on full disclosure, accountability and the truth. Since 1994

2 L. Wessels, "Good faith is not enough: We have to dialogue" in F. du Toit and E. Doxtader, In the balance: South Africans debate reconciliation (Auckland Park: Jacana Media, 2010), p. 9. 
discussions for a truth commission in South Africa began to occur in Parliament, the media and non-governmental organisations. South Africa had to balance the requirements of justice, stability, peace, accountability and reconciliation. In answering the question on how to deal with the atrocities of the past, the ANC preferred the notion of telling the truth via a truth commission process as the past could not be ignored. ${ }^{3}$ Alex Boraine expresses so clearly when he said:

\section{We accepted that it was necessary to turn the page of history, but first we needed to read that page. ${ }^{4}$}

A unique South African Truth and Reconciliation Commission was envisioned with the focus on the disclosure of truth through truth-telling, limited granting of amnesty and reparation for victims of gross violations of human rights. Establishing responsibility for violations and knowing the truth were essential for South Africa's transitional phase towards a future based on reconciliation and the recognition of human rights and dignity. ${ }^{5}$

The 'Promotion of National Unity and Reconciliation Act', Act No. 34 of 1995 (the Act) brought into being, empowered and mandated the Truth and Reconciliation Commission of South Africa. ${ }^{6}$ This marked the first time that a truth commission had been created through a public participatory process calling parliament to enable the creation of such a commission. The 17 Commissioners of the TRC were finally chosen in December 1995 by President Nelson Mandela and the Commission was geared to start. The group of Commissioners were multi-racial and were chosen to be impartial when executing verdicts and to be neutral towards the various political parties dealt with. Former Anglican Archbishop of Cape Town, the Very Reverend Desmond Tutu, became the Chairperson and Dr Alex Boraine the Deputy Chairperson of the TRC. ${ }^{7}$

The TRC employed roughly 300 people and consisted of four large offices around the country, thus making it, as far as possible, accessible to all people. The TRC's headquarters

J. de Lange, "The historical context, legal origins and philosophical foundation of the South African Truth and Reconciliation Commission" in C. Villa-Vicencio and W. Verwoerd (eds), Looking back, reaching forward: Reflections on the Truth and Reconciliation Commission of South Africa (Cape Town: University of Cape Town Press, 2000), p. 20; A. Boraine, A country unmasked. Inside South Africa's Truth and Reconciliation Commission (Cape Town: Oxford University Press, 2000), pp. 5-8, 11, 258-260; K. Christie, The South African Truth Commission (New York: Palgrave, 2000), pp. 33, 68, 79; D.M. Tutu, No future without forgiveness (London: Rider Books, 1999), p. 45.

Boraine, A country unmasked ..., p. 5.

J. Sarkin, Carrots and sticks: The TRC and the South African amnesty process (Schoten: Intersentia Publishers, 2004), p. 9; A. Boraine, "South Africa's Truth and Reconciliation Commission from a global perspective" in C.L. Sriram and S. Pillay (eds), Peace versus justice? The dilemma of transitional justice in Africa (Scottsville: University of KwaZulu-Natal Press, 2009), p. 137.

$6 \quad$ Republic of South Africa, "Promotion of National Unity and Reconciliation Act ...", pp. 148.

L.S. Graybill, Truth and reconciliation in South Africa: Miracle or model? (London: Lynne Rienner Publishers, 2002), p. 4; O. Bubenzer, Post-TRC prosecutions in South Africa: Accountability for political crimes after the Truth and Reconciliation Commission's amnesty process (Leiden: Nijhoff, 2009), pp. 9-10; C.L. Sriram, Confronting past human rights violations: Justice vs. peace in times of transition (London: Frank Cass, 2004), p. 154. 
were chosen to be located in Cape Town. ${ }^{8}$ The TRC was split into three interrelated committees. Firstly, the Human Rights Violations (HRV) Committee, which collected victims' and witnesses' accounts of stories in order to establish whether gross violations of human rights had occurred. The HRV Committee conducted open hearings throughout the country to give victims the chance to testify about their experiences. Secondly, the Amnesty Committee's primary function was to consider applications for amnesty. This Committee processed, facilitated and promoted the granting of amnesty in respect of those acts associated with political objectives of persons desiring to make a full disclosure of all the relevant facts relating to such acts. Lastly, the Reparations and Rehabilitation Committee which was responsible for providing recommendations to the President for the contribution of reparations and compensation for those found to be victims. An Investigative Unit was also created which performed inspective studies. ${ }^{9}$

South Africa's TRC was truly exceptional at that stage compared to previous commissions from around the world. It tested new boundaries and had very ambitious goals. ${ }^{10}$ The Commission was the first to facilitate victim hearings in the public arena whilst also giving perpetrators a chance to give their side of the story, and eventually granted individual amnesty if the perpetrator qualified for it. Public participation was deemed crucial by the TRC. Victims and perpetrators were significantly involved in the TRC process giving them a sense of having important input in the process. Therefore, the TRC had the power to grant individual amnesty to perpetrators, search properties, confiscate evidence, subpoena eyewitnesses and protect testifiers in a witness-protection programme. ${ }^{11}$

The TRC focused on exposing and investigating gross human rights violations from the time period 1 March 1960 to 10 May 1994. A gross human rights violation was defined as the

\section{violation of human rights through the killing, abduction, torture or severe ill treatment of any person. ${ }^{12}$}

Victims were encouraged to submit their written testimonies of the violations committed against them to the TRC. Of the 21296 written statements the TRC received, 1818 individuals were invited to come and give their testimonies in the public hearings of the TRC as their stories were considered broadly representative or 'window cases'. A total of $86.9 \%$

Boraine, "South Africa's Truth and Reconciliation Commission from a global perspective", p. 138.

9 Truth and Reconciliation Commission, Truth and Reconciliation Commission of South Africa Report (Cape Town: Juta \& Co, 1998), Vol. 1, pp. 267; 277, 285; P.B. Hayner, Unspeakable truths. Transitional justice and the challenge of truth commissions ( $2^{\text {nd }}$ edition), (New York: Routledge, 2011), p. 28.

10 Boraine, "South Africa's Truth and Reconciliation Commission from a global perspective", p. 150.

11 A. Krog, "To exchange justice for truth is to embrace evil: A view on human rights through the South African Truth and Reconciliation Commission", <http://www.ahrcentre.org/node/310>, 2002; D. Backer, "Victims' responses to truth commissions. Evidence from South Africa" in M. Ndulo, (ed.), Security, reconstruction, and reconciliation. When the wars end (New York: University College London Press, 2007), p. 192. See also the Act.

12 Republic of South Africa, "Promotion of National Unity and Reconciliation Act ...", p. 4. See also the Act for more details on what a gross human rights violation constituted. 
statements were made by Africans and an insignificant number of only $1.1 \%$ of White people made statements. More men testified in the White, Coloured and Asian groups opposed to the overwhelming majority of women in the Black population. These women did not in fact testify about their own experiences; instead, they testified about their male family members' ordeals. ${ }^{13}$

The TRC incorporated restorative justice and was based on the Christian concept of 'forgiveness' and the African view of 'ubuntu'. Restorative justice aspires to aid nationbuilding and reconciliation by aiming to improve social relations in a country. It focuses on the well-being of the victim, as well as the perpetrator being successfully integrated back into the community. The word 'ubuntu' features in the Nguni group of languages and means essentially 'being human'. It symbolises the fact that all people are interdependent on one another. Each person has an important role to play in his/her society to ensure peace and prosperity for all. ${ }^{14}$

The national and international media covered the proceedings and results extensively, with daily articles in the newspapers and reports on the television. ${ }^{15}$ The TRC compiled a fivevolume Final Report which was made available in October 1998. Report volumes six and seven were finished in 2002 and published in 2003. ${ }^{16}$

The TRC has been widely praised for what it eventually accomplished and achieved. The Commission has also been criticised for being a complete failure. Anthea Jeffery criticises the TRC by emphasising that:

\section{The commission has done as much to distort as to disclose the truth. Its approach was selective rather than comprehensive. Some parts of its report are simply sloppy. The methods used by the TRC are deeply flawed. From flawed methods flow flowed conclusions. The commission has issued a report, which can only be of an interim and tentative nature. In fact, what the commission has done is to focus on only half the story - and to tell that half in a selective and distorted way. ${ }^{17}$}

However, the TRC did focus on ordinary citizens and aimed to make the process understandable for all. Involvement in the TRC processes caused citizens to be more accepting, tolerant and respecting of other races and their different political views which

Boraine, $A$ country unmasked..., p. 115; P. Govender, "Truth, reconciliation and women in South Africa" in Du Toit and Doxtader, In the balance ..., p. 77.

H. Cobban, Amnesty after atrocity? Healing nations after genocide and war crimes (Boulder: Paradigm Publishers, 2007), p. 10; C. Villa-Vicencio, Walk with us and listen: Political reconciliation in Africa (Cape Town: UCT Press, 2009), p. 114; Tutu, No future ..., p. 34; R.A. Wilson, The politics of truth and reconciliation in South Africa: Legitimizing the PostApartheid State (Cambridge: Cambridge University Press, 2001), p. 205; C. Villa-Vicencio, "Reconciliation" in C. Villa-Vicencio \& E. Doxtader (eds), Pieces of the puzzle: keywords on reconciliation and transitional justice (Cape Town: Institute of Justice and Reconciliation, 2004), p. 5.

Boraine, "South Africa's Truth and Reconciliation Commission from a global perspective", pp. 138-139.

P.J. Salazar and E. Doxtader, Truth \& reconciliation in South Africa: The fundamental documents (Claremont: New Africa Books, 2007), pp. xii-xiii. 
encouraged democracy in South Africa. ${ }^{18}$ According to Alex Boraine, the TRC of South Africa was a valuable experience and other countries in similar post-conflict situations may learn from the unique TRC of South Africa. ${ }^{19}$ The citizens had a shared responsibility of blame for apartheid which provided a basis for discussions. People on all sides were hurt and shocked to find out what really took place during the apartheid regime in South Africa. A process of reconciliation could be set in motion between South Africans, hopefully paving the way to a more peaceful and tolerant society in the country.

\section{Understanding the concept and process of reconciliation}

Reconciliation can be explained as the willingness of people from different ethnicities and race to cultivate trust in one another and to live in harmony with despite their differences. It includes the discouragement of keeping condescending stereotypes about different races which may lead to hostility and violence. Most importantly, reconciliation contributes to a country's sustainability of democracy. It can also be accomplished through non-racialism, unbiased behaviour, religion and enhancing community relationships. ${ }^{20}$

Reconciliation consists of both social rehabilitation and conflict resolution which ensures long-term peace in a country with a conflict ridden past. Thus, it changes people's negative attitudes towards one another and creates innovative relationships among them. When people interact with one another they find a new understanding of the other which assists in building a bridge to eventually reach reconciliation. However, it remains neither a direct nor immediate solution to differences among people. Furthermore, reconciliation cannot be forced on or implemented by a person, organisation or institution as it can only systematically take place within a person over time. ${ }^{21}$

Reconciliation may take place when a person has empathy, understanding and is even forgiving towards other people. Forgiveness is also believed to set the path to reconciliation which creates a peaceful society; the two concepts go hand-in-hand. People are set free from their hideous memories and can move on to be part of a reconciled society if they let go of all their bitterness. Feelings of empathy and acceptance towards the perpetrator may even surface. It is then that forgiveness can set free both the person forgiving and the person who is forgiven. Refusing to forgive may make one's life despondent, as well as negatively affecting

J.L. Gibson, "The truth about truth and reconciliation in South Africa" in International Political Science Review 26(4), October 2005, p. 344; J.L. Gibson, "The contributions of truth and reconciliation: Lessons from South Africa" in The Journal of Conflict Resolution 50(3), June 2006, p. 413.

M.M. Oelofse Private Collection, Interview with A. Boraine, 13.7.2007, Cape Town.

J.L. Gibson, Overcoming apartheid: Can truth reconcile a divided nation? (Cape Town: HSRC Press, 2004), pp. 4-5; P. Gready, The era of transitional justice. The aftermath of the Truth and Reconciliation Commission in South Africa and beyond (Milton Park: Routledge, 2011), p. 58; A. Krog, Country of my skull ( $2^{\text {nd }}$ edition), (Johannesburg: Random House, 2002), p. 36. 416; Boraine, A country unmasked ..., p. 8; Gready, The era of transitional justice ..., p. 156; H. van der Merwe and B. Hamber, "What is this thing called reconciliation?", <http://www.csvr.org.za/articles/artrcb\&h.htm>, 2011; Sarkin, Carrots and sticks ..., p. 34; Villa-Vicencio, "Reconciliation", p. 4; Villa-Vicencio, Walk with us and listen ..., pp. 152,172; Wilson, The politics of truth and reconciliation ..., p. 98. 
those around one. Yet, forgiving a person can never be predicted or forced; it can only happen within the person forgiving. ${ }^{22}$

There is also no set design to follow when achieving reconciliation. It must be a continuous process; unending through all generations. Some people believe that reconciliation should take place from the bottom up. This means that it should start in local and domestic communities and end with the national community. ${ }^{23}$

The process of reconciliation has been described as the only practical alternative for a society in transition to live in harmony with one another. Thus, reconciliation may ensure a peaceful environment in South African society as it was and still is, an idyllic outcome longed for in South Africa. ${ }^{24}$

However, reconciliation is a relatively new concept for South Africans as Apartheid taught people to be segregated and condescending towards people of different races. The first step towards reconciliation in South Africa started through the termination of conflict through negotiations and not through the collapsing of the former regime or through victory in the field..$^{25}$

The South African TRC vaguely classified reconciliation as a process and a desired outcome in South Africa but never gave a set layout in the Act of specific processes in reaching it, or even officially describing what was meant by their idea of 'true reconciliation' for the country. The Commission mainly aimed to promote reconciliation through revealing the truth and expressed that it is not an easy method. The TRC believed that the more truth is revealed about the past, the greater the possibility of reconciliation taking place. $^{26}$

The TRC made the following recommendations in Volume 5 of the Final Report to set in motion a process of reconciliation and unity in South Africa's future. They requested that all South Africans should reach out to one another and be more tolerant and understanding. Barriers should be crossed in terms of language and religion so that better relationships could be formed between South Africans. People should also be aware of the special needs of the previously disadvantaged, such as women and children. A culture of debate should be pursued so that issues can be resolved and eventually lead to the creation of a non-racial society. Finally, the leaders in the local, provincial and national government should make reconciliation and unity a priority on their agendas. ${ }^{27}$

F.W. de Klerk, "The need for forgiveness and reconciliation" and A. Krog, "This thing called reconciliation: forgiveness as part of an interconnectedness towards wholeness" in Du Toit and Doxtader, In the balance ..., pp. 32, 141; Gready, The era of transitional justice ..., p. 201. Wessels, "Good faith is not enough: We have to dialogue", p. 11; Villa-Vicencio, Walk with us and listen ..., p. 172; Gready, The era of transitional justice ..., p. 158; Truth and Reconciliation Commission, Truth and Reconciliation Commission of South Africa Report, Vol. 5, p. 306; Christie, The South African Truth Commission, pp. 143, 204. Villa-Vicencio, "Reconciliation", p. 3; Villa-Vicencio, Walk with us and listen ..., pp. 170-172. Historical Papers, University of the Witwatersrand, The Kairos Collection, AG2918: 4.5.4 Articles, Villa-Vicencio, "From coexistence to reconciliation. The TRC: A step along the way", 8-9 February 1998, p. 1; Gibson, Overcoming apartheid ..., p. 15. Salazar and Doxtader, Truth E reconciliation in South Africa ..., p. xiii; Wessels, "Good faith is not enough: We have to dialogue", p. 9. Truth and Reconciliation Commission, Truth and Reconciliation Commission of South Africa Report, Vol. 5, p. 304. 
Critics believed that the TRC did not make enough efforts towards ensuring reconciliation in the end. People believed that reconciliation would occur automatically after the TRC processes had taken place, but this was not the case. ${ }^{28}$ Charles Villa-Vicencio argues that truth-telling processes do not always lead to reconciliation. Victims and/or perpetrators were sometimes enraged by the truth which hindered future reconciliation. Expecting victims of gross violations of human rights in South Africa to reconcile has been a greatly debated subject. For many victims of gross violations of human rights in the country, the memories of suffering are too painful and reconciliation is not always an option. ${ }^{29}$

Following the TRC's processes there are still arguments about the real meaning of reconciliation: who are making real efforts towards it; if the process has really begun and if it is continuing in South Africa? A reconciled South Africa would ideally consist of people who respect and trust people from different races; who are tolerant towards people with diverse political views; who believe that all South Africans are entitled to their human rights and are equal no matter the race. ${ }^{30}$ It is clear that the process of reconciliation may have been encouraged by the TRC, but continues to be every South African citizen's responsibility.

\section{$4 \quad$ Research methods and approach}

The problem statement was an empirical question: What is the knowledge and perceptions of registered undergraduate history students at the University of the Free State's (UFS) main campus regarding South Africa's Truth and Reconciliation Commission (TRC) and the concept and process of reconciliation in the country?

Answering this question is of importance to firstly assess if the younger generation of students, specifically students taking history as a subject, have any knowledge of such a significant and contemporary event in South African historiography as the TRC process. Secondly, to gauge, in relation to the aims and recommendations of the TRC and against the background of the efforts been made by the UFS on reconciliation, to perceive the views and thoughts of undergraduate history students on the progress of reconciliation efforts in South Africa.

The study is of a contemporary nature, with data that were collected in 2012 in Bloemfontein at the University of the Free State's main campus. A sample of 128 registered undergraduate history students were randomly selected and asked to voluntarily complete a questionnaire individually during undergraduate History classes' scheduled time. Thus, the questionnaires were completed by the participants at the same time, making the response rate optimal. Questionnaires as a quantitative method of gaining information were distributed amongst the first-, second- and third-year History students. The questionnaire, which consisted of 20 questions, focused on factual questions, as well as opinionated questions which included both open-ended and closed questions. All responses to the questionnaire were done in an anonymous manner and the questionnaire measured what it was intended to measure. The

\footnotetext{
28 Truth and Reconciliation Commission, Truth and Reconciliation Commission of South Africa Report, Vol. 5, p. 306.

29 Villa-Vicencio, "Reconciliation”, pp.3-4; Gready, The era of transitional justice ..., p. 160; C. Villa-Vicencio, "Reconciliation: a thing that won't go away" in Du Toit and Doxtader, In the balance ..., p. 161. 
questionnaires' validity was tested through content validity by submitting the questionnaire beforehand to two historians to evaluate the questions and to determine if it is actually measuring what it is intended to do.

To supplement the quantitative data, multiple respondents from the undergraduate history students from different year groups, who completed the questionnaire, were selected randomly to be voluntarily interviewed in two diverse group sessions and answers/feedback were recorded. To emphasise the confidentiality of their opinions and remarks, the interviewees were recorded anonymously by not using the students' names, but by referring to them as respondent 1,2 , etc. The fact that South Africa is a country with a democratic system, made it easy for students who participated in the questionnaire, as well as in the interview process to freely express their opinions and statements. Answers and results from the questionnaire guided the questions for the interviews. These questions were structured in such a way as to gain data to be qualitative in nature, thus explanatory orientated, giving the researcher in-depth and breadth information to the answers from the questionnaire. This was a dynamic process based on interaction between various students. These focus group interviews were used as a holistic approach to gain knowledge to be used in a complementary way with the questionnaire to create a more multifaceted understanding of the students' knowledge and views on the topics under research.

Questionnaire results were analysed in order to compile the profile and frequencies of the data. During this phase the quantitative results were summarised, interpreted and compared with the information further gained from the qualitative data.

Thus, for the purposes of this research, an explanatory mixed-method research method approach was undertaken where both the qualitative and quantitative methods were implemented. The reason for this was to be able to gain more comprehensive and insightful results, as well as to provide a fuller understanding of the research problem.

\section{Results of the research}

The 128 undergraduate students who take History as a subject at the University of the Free State (UFS) main campus who completed the questionnaire individually are students from diverse socio-cultural backgrounds. The youngest person who completed the questionnaire was 18 years old and the oldest person was 42 years of age. The average age of the students who completed the questionnaire was between 20 and 21 years of age. Out of 128 people completing the questionnaire, 123 were citizens of the Republic of South Africa. There were five other nationalities, namely American, Belgian, French, Cameroonian and Namibian. Sixty-seven women completed the questionnaire compared to 61 men.

According to James L. Gibson, it is impossible to write about South African politics without focusing on race and is it common to divide the population into four distinct categories of race. ${ }^{31}$ For the purposes of this article, Gibson's line of argument will also be followed and used. ${ }^{32}$ The History classes consist of diverse races; therefore, the results of the questionnaires

31 Gibson, Overcoming apartheid ..., p. 24.

32 For the purpose of this study the term 'Black', 'Coloured' and 'Indians' are used. By using these terms, no negative connotation or prejudice is implied towards the people grouped in this way. 
were also evaluated according to race to be able to explain the demographic qualities. In 2012 the UFS had the largest portion of black students of the historically Afrikaans universities; over all campuses $70 \%$ of the student population is black. ${ }^{33}$ With answering the questionnaire, Black students were in the majority with $69.5 \%$; White students who participated amounted to $21.9 \%$, Coloured students were $7.8 \%$ and Indian students had only $0.8 \%$ representation. There clearly exists a gap on Indian students' knowledge and opinions towards this research as only one Indian female student completed a questionnaire. Her opinions could not be utilised to represent the student population as a whole.

\subsection{Knowledge about the TRC}

When students were asked about their knowledge regarding the TRC (question 1), the majority knew only a little (59.4\%). Others indicated that they knew a great deal (32\%), 7\% had never heard about it and $1.6 \%$ said they were not interested in the TRC at all. When the results were examined closer, only $17.9 \%$ of White students claimed to know a great deal about the TRC in contrast to the $37.1 \%$ of Black students and 30\% of Coloured students. Gender does not really play a role as male and female students claimed to know more or less the same with $91.8 \%$ of males and $91.1 \%$ of females stating that they know something about the TRC of South Africa.

\begin{tabular}{|c|c|c|}
\hline \multirow{4}{*}{$\begin{array}{c}\text { Claim to have little } \\
\text { knowledge about } \\
\text { the TRC }\end{array}$} & White Students & $67.9 \%$ \\
\cline { 2 - 3 } & Coloured Students & $60 \%$ \\
\cline { 2 - 3 } & Black Students & $56.2 \%$ \\
\hline
\end{tabular}

Table 1: Descending order of alleged knowledge about the TRC

As seen in Table 1 is it evident that White and Coloured students claim to have very little knowledge on the TRC in relation to the Black students. This is confirmed when the $14.3 \%$ of White students asserted that they had never heard about the TRC in relation to only $5.6 \%$ of Black people who had never heard of the TRC.

This 'little knowledge' about the TRC was further emphasised by the students' answers to the second question where $46.9 \%$ of them had been told 'a little' about the TRC by their family and/or friends. From the rest of the respondents, $39.1 \%$ had been told nothing by their family and/or friends and $14.1 \%$ had supposedly been told a great deal. From the answers to question 4 it appears that the students gained most information and knowledge about the TRC at school and university, as well as from media sources, such as the television and newspapers.

The absence of knowledge about the TRC is reflected further when only $44.5 \%$ accurately chose the correct objective of the TRC (question 7), which was to establish as complete a picture as possible of gross violations of human rights and to create a culture of reconciliation

33 University of the Free State, "University of the Free State Strategic Plan 2012-2016", <http://www.ufs.ac.za/content.aspx?id=57>, 2012, p. 17. 
in South Africa; 55.5\% chose the wrong definition by saying that the TRC established reconciliation in South Africa.

However, in stark contrast to these results and indeed surprisingly, 57.8\% correctly identified April 1996 as the date of the first victim hearing which was held in East London (question 8). Taking into account the high percentage of "little knowledge about the TRC" from the participants, one may conclude that answering this question correctly was based more on a 'correct guess', than of having the correct, in-depth knowledge.

Knowledge about the TRC appears to be limited among the undergraduate history students at the UFS main campus. The impression is that adult family members have not really exposed them to information about the TRC, and amongst their peers it is not a frequently discussed and debated topic.

Nonetheless, on a more positive note, the results from question 12 indicated that $75 \%$ of students would like to learn more about the TRC. For $18.7 \%$ it is a 'maybe', while $5.5 \%$ of students are not interested at all, and $0.8 \%$ are indecisive. Again, it is the White students who are more reluctant about knowledge on the TRC with $17.9 \%$ specifying that they do not wish to learn more about the TRC, compared to the $2.2 \%$ of Black students.

\subsection{Views on the TRC}

Most of the students were neutral (44.5\%) when asked if their family was positive about the TRC process (question 3). The lack of knowledge and dialogue about the TRC were repeated in the answers to this question when $34.4 \%$ did not know how their family felt about the TRC. For $14.8 \%$ their family was positive, while $6.3 \%$ of students were frank when they revealed that their family was not positive about the TRC process.

$14.3 \%$ of White students, compared to $15.7 \%$ of Black students and only $10 \%$ of Coloured students indicated that their families were positive about the TRC process. The majority of White students (42.9\%) did not know how their family felt about the TRC process compared to the $33.7 \%$ of Black students and $10 \%$ of Coloured students who were also unaware of their family's opinions towards the TRC. More female respondents (19.4\%) felt that their family was positive in relation to $9.8 \%$ of males.

\begin{tabular}{|c|c|c|}
\hline \multirow{4}{*}{$\begin{array}{c}\text { Are you positive } \\
\text { about the establishment } \\
\text { of the TRC? }\end{array}$} & Yes & $63.3 \%$ \\
\cline { 2 - 3 } & Neutral & $22.7 \%$ \\
\cline { 2 - 3 } & No & $8.6 \%$ \\
\cline { 2 - 3 } & Do not know & $5.5 \%$ \\
\hline
\end{tabular}

Table 2: Results of the students' answers on how positive they are about the establishment of the TRC 
Although knowledge about the TRC seems to be limited, students were overwhelmingly positive about the establishment of the South African TRC (question 5). See Table 2.

Surprisingly and even contradictory to the previous results on the negative perspectives and limited knowledge from the White students on the TRC, $64.3 \%$ of these students felt positive about the establishment of the TRC in relation to the $61.8 \%$ of Black students. The highest percentage was from the Coloured students with 70\%. More Black students $(10.1 \%)$ indicated that they are not positive about the TRC compared to the $7.1 \%$ of White students who were also unconvinced about the TRC.

Once again, taking into account the limited knowledge of the TRC, one tends to wonder if the positive indication towards the establishment of the TRC is a true reflection of a knowledgeable answer having been made to this question.

\section{How did the TRC process and what was revealed about South Africa's past, make you feel?}

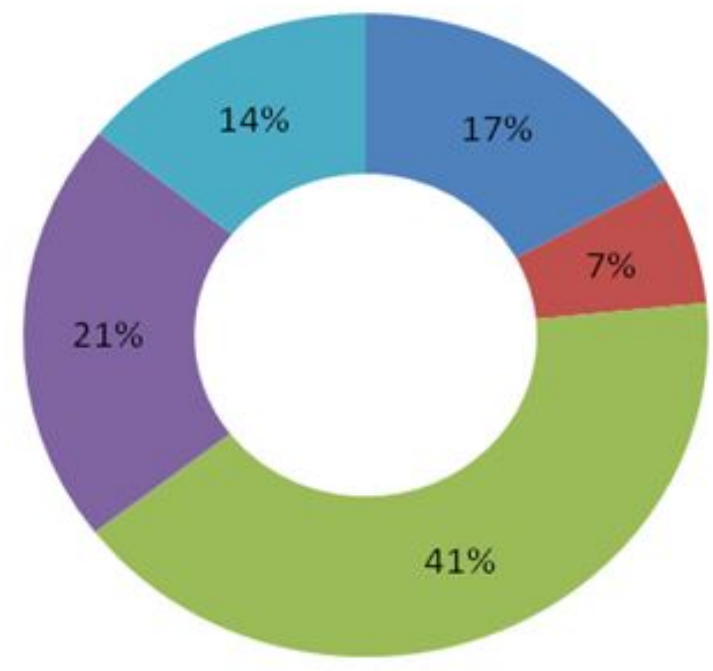

- Sense of Dignity and self-respect

aroud

neutral

ashamed

Sense of dishonour

Figure 1: Students' opinions about the TRC process and what was revealed about South Africa's past

As seen in Figure 1, the majority of students felt neutral (41\%) about the TRC's process and what was revealed about South Africa's past (question 6). Students also signified that they felt ashamed (21.3\%) and felt a sense of dishonour (14.2\%). For $17 \%$ of students the TRC's processes made them feel a sense of dignity and self-respect with $6.5 \%$ who were proud.

The majority of Black students felt ashamed (24.7\%) and a sense of dishonour (18\%), compared to the White students' responses of $21.4 \%$ feeling ashamed and $10.7 \%$ having a sense of dishonour. A mere 3.6\% of White students and $9 \%$ of Black students felt proud about the TRC's processes. In contrast to this $7.1 \%$ of White students, $23.6 \%$ of Black students and $10 \%$ of Coloured students had a sense of dignity and self-respect towards what was revealed about South Africa's past (Figure 2). 


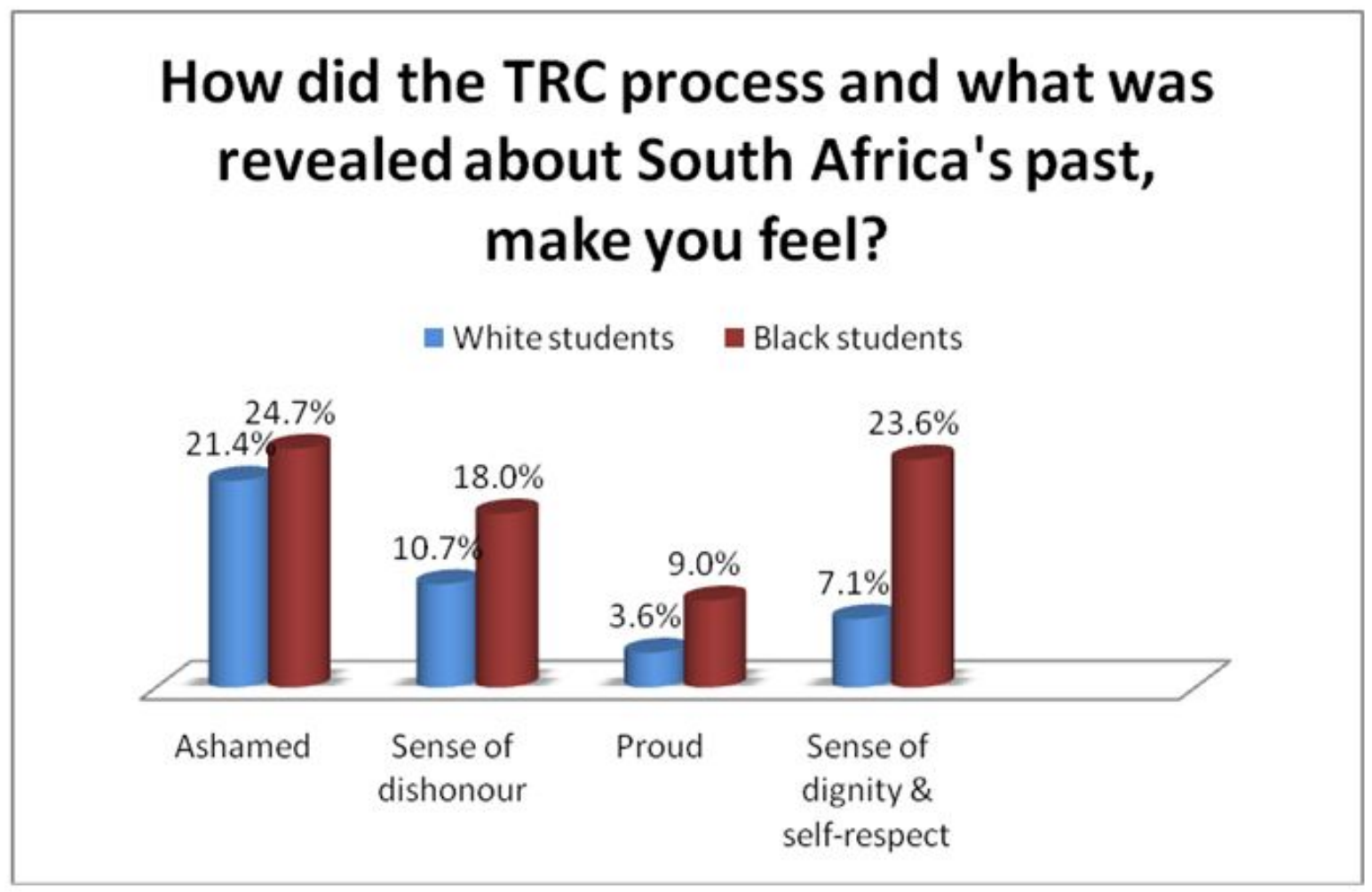

Figure 2: Black and White students' outlook towards the TRC process

Research regarding the TRC reveals that the process was, at first, predominantly viewed as positive and victims were supportive of the idea of a TRC. However, not all viewed the TRC with the same enthusiasm afterwards. It seems as if some victims had over-inflated expectations from the TRC. Misunderstandings concerning the role of the TRC also surfaced amongst South Africans. ${ }^{34}$ It could be that these unmet and mistakenly high expectations may have had an influence on particularly Black students' negative responses concerning their feelings towards the TRC process and what was revealed.

When asked about the TRC's contribution to enhancing relations between different population groups in South Africa (question 9), the majority again chose the neutral option (35.2\%) with 32\% indicating the TRC's contribution as 'good'. This neutral option was chosen by $21.4 \%$ of White students, $13.5 \%$ of Black students and $20 \%$ of Coloured students who were unsure about how they felt about the TRC's contributions. The other opinions were 'very bad' (3.9\%), 'bad' (7.8\%) and 'very good' (5.5\%). 15.6\% of students did not know how they felt about the TRC's contributions to enhancing relations between different population groups. $18 \%$ of males tended to be more negative about the contribution of the TRC to enhancing relations between different population groups compared to only $6 \%$ of females.

The majority of students, $67.2 \%$ pointed out that the TRC improved the reconciliation processes in South Africa against the $32.8 \%$ who thought that the TRC did not (question 10). As seen in Figure 3, the majority of White students (75\%) agreed that the TRC 
improved reconciliation in South Africa compared to $65.2 \%$ of Black students and $60 \%$ of Coloured students.

\section{Students with the opinion that the TRC improved reconciliation in South Africa}

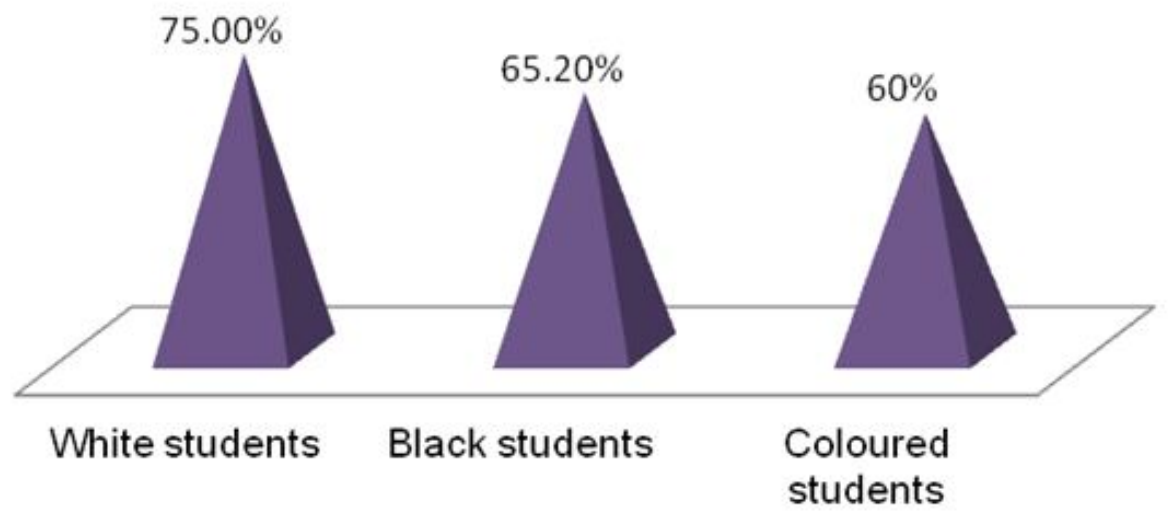

Figure 3: Percentage of students who agree that the TRC has improved reconciliation in South Africa

Again, it is the female gender group which is more positive towards the processes of the $\mathrm{TRC}$, as well as its contribution to improving the reconciliation processes with $73.1 \%$ compared to only $60 \%$ of males (Figure 4 ).

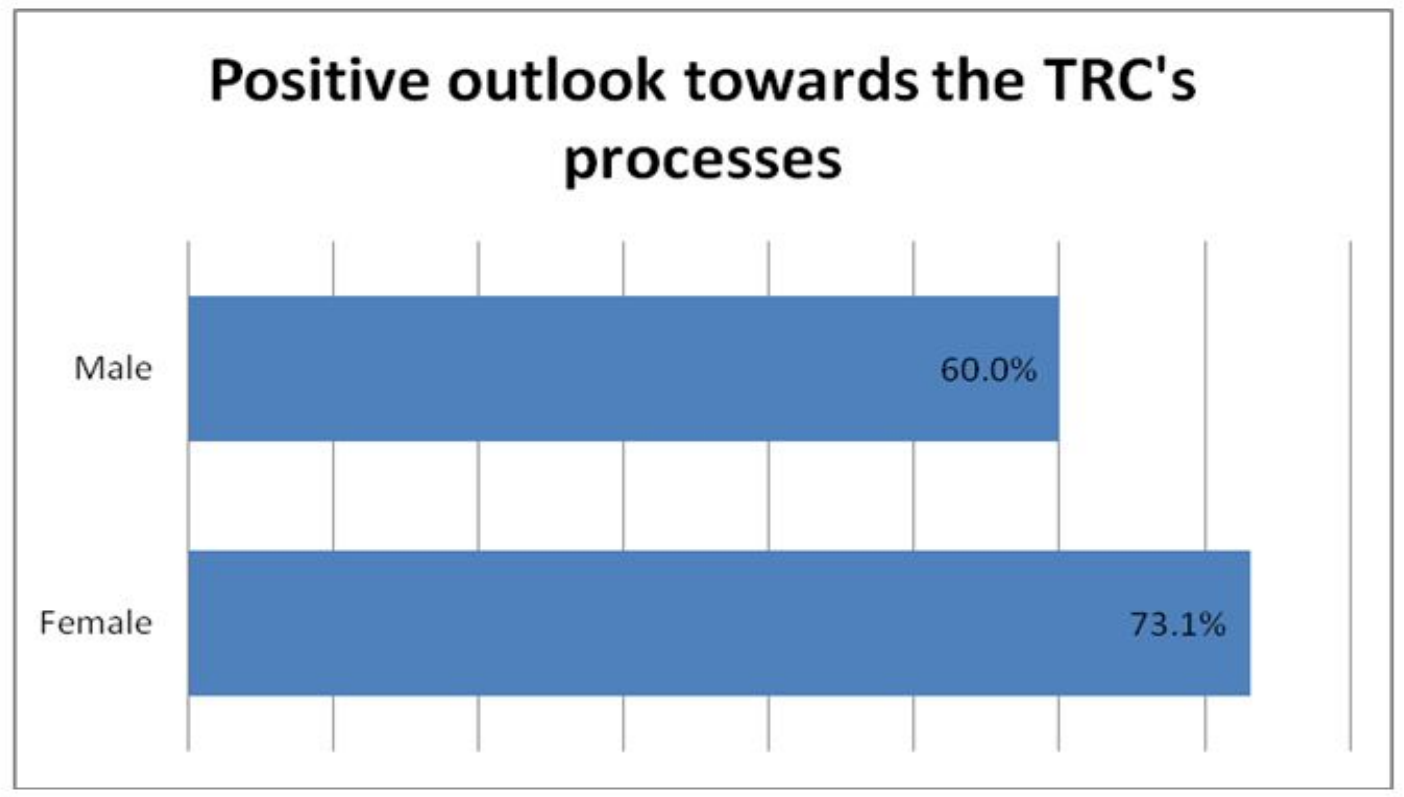

Figure 4: Comparing gender-based positive views about the TRC's processes

The students' responses are relatively high compared to the Reconciliation Barometer of 2011, which indicated that only 47\% of people thought that the TRC improved the reconciliation processes in South Africa. According to the Barometer the research participants described conditions in South Africa after the TRC as a "peaceful coexistence" 
rather than "true reconciliation", where the latter was described as "pretence" and a "distant dream". ${ }^{35}$ This notion is confirmed by previous surveys which found that almost two-thirds of urban South Africans thought that the TRC harmed rather than reconciled race relations between South Africans. ${ }^{36}$

When questioned (question 11) if the Final Report of the TRC was a true reflection of South Africa's past, $28.1 \%$ of the students agreed with this statement and $25 \%$ were neutral; $6.3 \%$ strongly agreed in contrast to $5.5 \%$ who strongly disagreed and $14.8 \%$ who disagreed with this statement. The $20.3 \%$ who did not know, once again emphasises the lack of insight and knowledge about the TRC.

There seems to be relatively high percentages of 'neutral' responses to questions asked about students' personal feelings about the TRC. This may be due to the fact that the students have limited factual knowledge about the TRC and what it entailed to truly have a thoroughly informed own opinion about the TRC, its aftermath, and the continuous process of reconciliation that the TRC was aiming for in South Africa.

\subsection{Knowledge about reconciliation in South Africa}

Students were asked to define the concept 'reconciliation' in question 13 . The majority of students (39.1\%) believed that it entailed forgiving perpetrators, and a form of healing that takes place; $20.3 \%$ indicated that it meant establishing peace between different races and $18.8 \%$ described reconciliation as unity between different races. $8.6 \%$ of students vaguely spoke of reconciliation as a state where no racism exists between people. The other $13.2 \%$ of students could not define the concept. The concept reconciliation remains difficult for people to define as the word is constantly used in different contexts in South Africa, making it difficult to establish the real meaning. People may not be able to precisely pinpoint what reconciliation entails but seem to "know it when they see it". ${ }^{37}$

In the opinion of the students to question $15,75 \%$ indicated that justice and reconciliation are linked. This concurs with the view of most victims who generally feel that justice must happen if the desire for reconciliation is to take place. ${ }^{38}$ Furthermore, $92.2 \%$ of students thought that reconciliation is necessary for post-conflict reparation and reconstruction for a peaceful South Africa, with $7.8 \%$ thinking that reconciliation is not necessary.

Responses to the question if the process of reconciliation is easy, the vast majority of $96.1 \%$ indicated that the statement is 'False'. Maybe from their own experiences with intergroup relations, it seems that the students are aware that the process of reconciliation is not instant and takes time. ${ }^{39}$ When asked if forgiveness and reconciliation go hand-in-hand, students understood that it is always the case (53.1\%), sometimes the case (45.3\%) and never the case $(1.6 \%)$.

As seen in Figure 5, the 'neglect' of reconciliation is reflected in the students' answers to question 20 . Only $13.3 \%$ of students indicated that they regularly discuss reconciliation with

K. Lefko-Everett et al., SA reconciliation barometer survey: 2011 Report (Cape Town: Institute for Justice and Reconciliation, 2011), p. 42.

36 Oelofse, Remembering the truth ..., pp. 150-151.

37 Gibson, Overcoming apartheid ..., p. 12.

$38 \quad$ Villa-Vicencio, "Reconciliation", p. 3.

39 Villa-Vicencio, Walk with us and listen ..., p. 110. 
their friends; $46.1 \%$ said that they sometimes discuss reconciliation with $40.6 \%$ pointing out that they never discuss reconciliation with their friends.

\section{My friends and I discuss reconciliation:}

negularly $=$ Sometimes $=$ Never

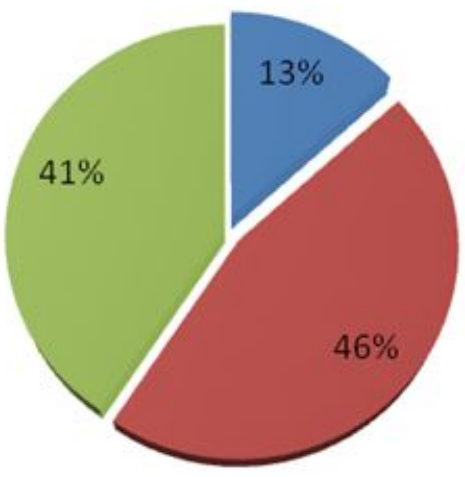

Figure 5: Students' responses to how often they discuss reconciliation

Deeper investigation revealed that $75 \%$ of White students and $40 \%$ of Coloured students never spoke about reconciliation compared to only $29.2 \%$ of Black students (Figure 6). Interestingly, males tended to discuss reconciliation more than females.

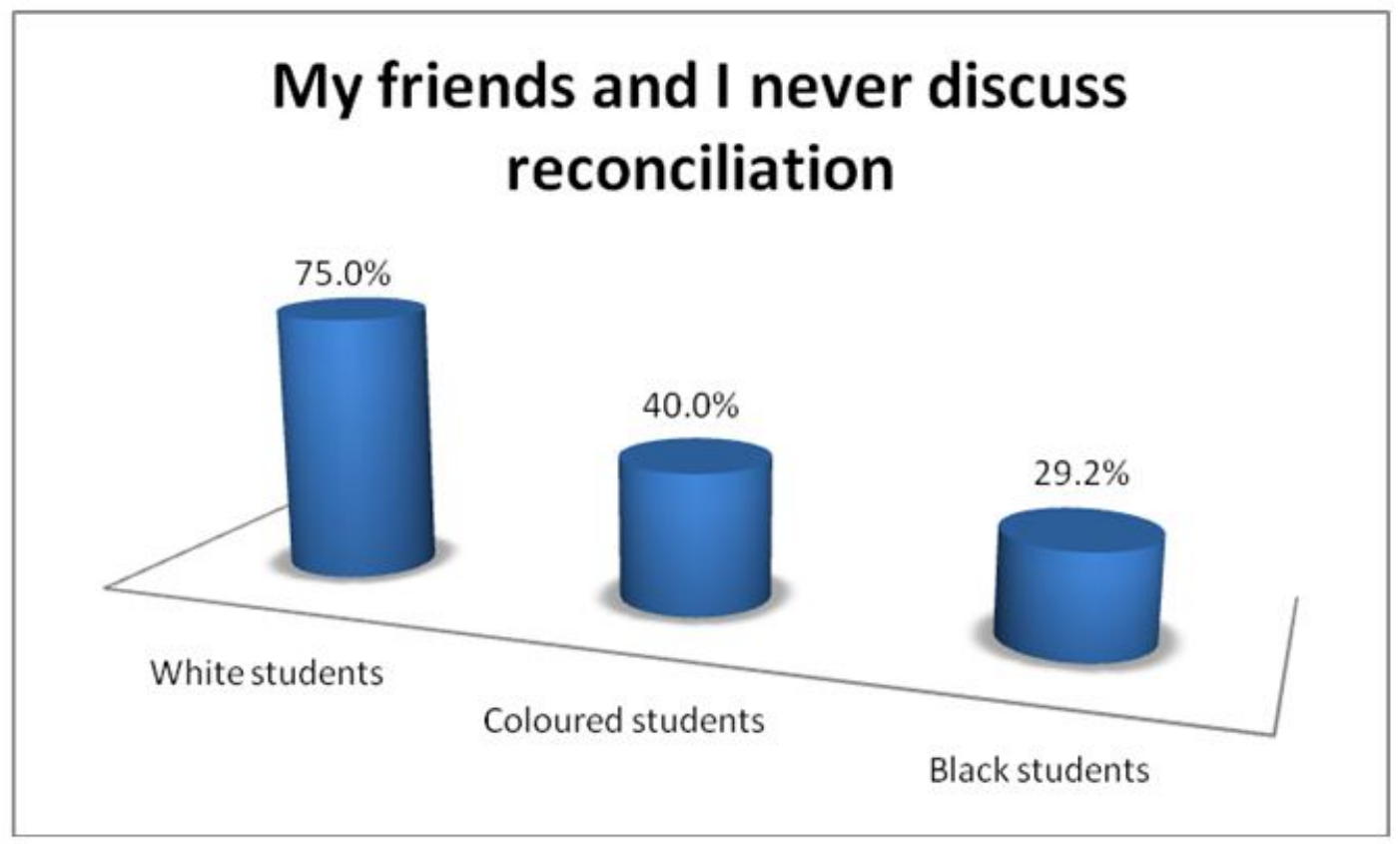

Figure 6: Percentage of students from different racial groupings who admitted to never discussing reconciliation with their friends 
Table 3 distinctly represents the inadequate knowledge of the students on the TRC and its reconciliation process as asked in question 14. Archbishop Desmond Tutu is clearly more well-known for his efforts in the reconciliation process of South Africa with 48\% acknowledging him. Only $11.4 \%$ of students know about the key role played by Alex Boraine. Startlingly, 28.7\% of students thought that Eugene de Kock and Joe Mamasela played a key role in the reconciliation processes in South Africa. Students are clearly unaware of the TRC's Chairpersons, let alone the more well-known perpetrators that were active during the former regime in South Africa.

\begin{tabular}{|c|c|c|}
\hline \multirow{6}{*}{$\begin{array}{l}\text { Who played a } \\
\text { key role } \\
\text { in the } \\
\text { reconciliation } \\
\text { processes of } \\
\text { South Africa? }\end{array}$} & Alex Boraine & $11.4 \%$ \\
\hline & Joe Mamasela & $10.6 \%$ \\
\hline & Eugene de Kock & $18.1 \%$ \\
\hline & Wouter Basson & $7.1 \%$ \\
\hline & Craig Williamson & $4.7 \%$ \\
\hline & $\begin{array}{c}\text { Archbishop } \\
\text { Desmond Tutu }\end{array}$ & $48 \%$ \\
\hline
\end{tabular}

Table 3: Students' responses when asked about the persons who played a key role in reconciliation processes

The results once again emphasise that undergraduate history students at the UFS main campus have a limited knowledge about the reconciliation processes in South Africa, let alone the TRC.

\subsection{Views about reconciliation in South Africa}

For $85.9 \%$ of students it is realistic to ask South Africans to reconcile, while $14.1 \%$ disagree (question 16). The students' optimism about the desire to reconcile is relatively high compared to the $66 \%$ of people who indicated in the Reconciliation Barometer of 2011 that it is the ultimate outcome for all. ${ }^{40}$ Interestingly, more Black students $(16.9 \%)$ believed that it is not realistic to ask South Africans to reconcile compared to only $10.7 \%$ of White students.

With reference to the students' own feelings towards reconciliation in South Africa (question 18 ), they were mostly neutral (39.8\%) but also a high percentage of $38.3 \%$ were positive. Other indications were very negative (3.9\%), negative (11.7\%) and very positive (6.3\%). Black students seemed to be more optimistic about reconciliation with $48.3 \%$ of students 
commenting positively and very positively on their feelings of reconciliation in relation to $39.3 \%$ of White students. Interestingly, only $20 \%$ of Coloured students had positive remarks towards their feelings of reconciliation.

It was also evident that more males $(24.6 \%)$ were pessimistic about reconciliation in South Africa compared to only $7.5 \%$ of females. This statement was confirmed once more when $53.8 \%$ of females indicated that they were optimistic towards reconciliation in contrast to $34.4 \%$ of males (Figure 7 ).

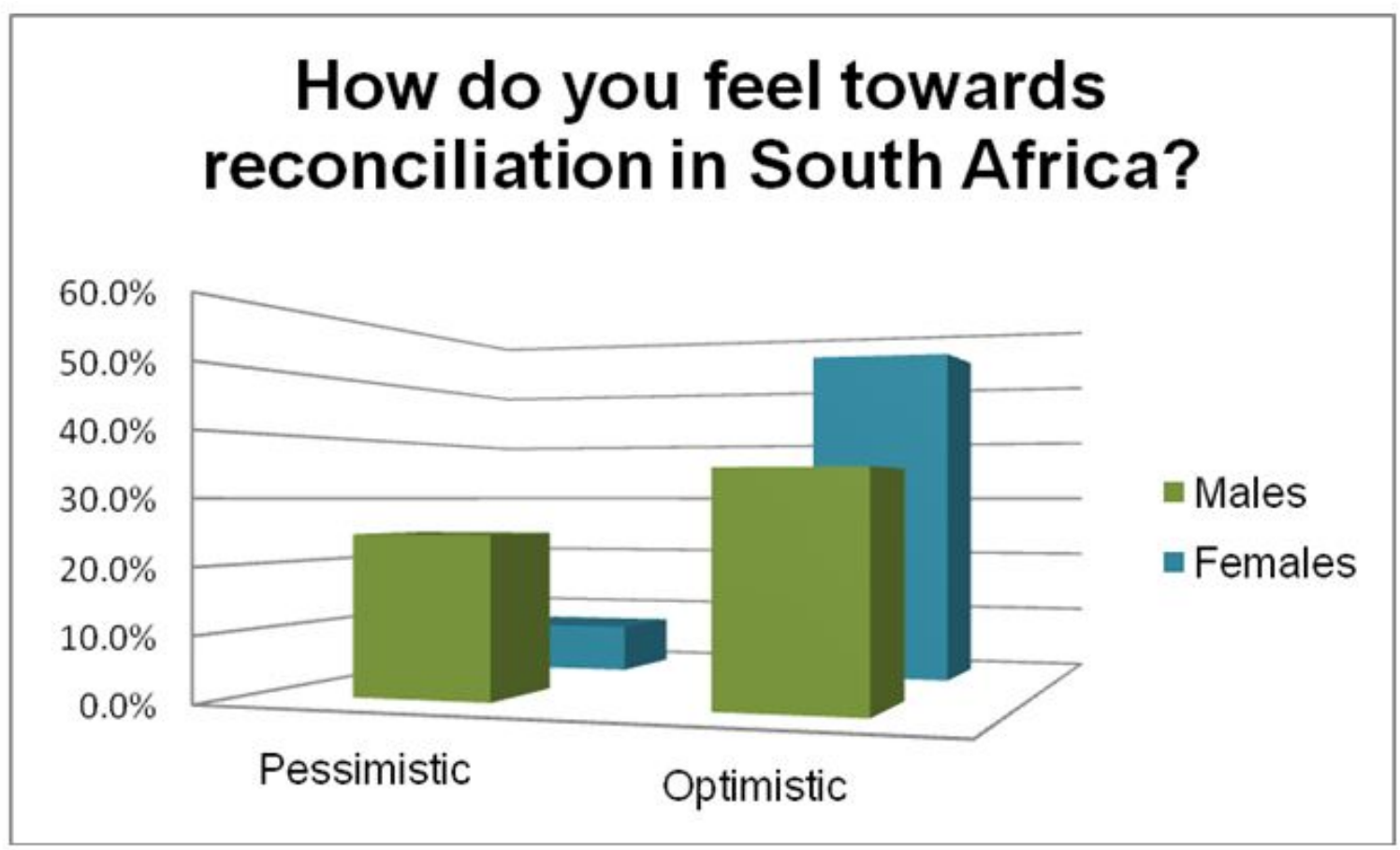

Figure 7: Gender-based views concerning reconciliation in South Africa

To ensure a peaceful South Africa (question 19), 55.5\% of students indicated that justice should be the first priority followed by reconciliation with $35.9 \%$. The other $8.6 \%$ said that equality, forgiveness, peace, as well as ending corruption in South Africa's governmental systems should be the main priority. The majority of White students $(60.7 \%)$ and $55.1 \%$ of Black students believed that justice should be the first priority in South Africa. The Coloured students are 50-50 with 50\% making the choice for justice and 50\% for reconciliation. 39.3\% of Black students believed that reconciliation should currently be the first priority with only $21.4 \%$ of White students who clearly are doubtful that reconciliation should be the main concern in South Africa.

During the group session interviews with students, all 16 respondents indicated that South Africa is definitely not reconciled yet. They rated reconciliation in South Africa between 3050\%. ${ }^{41}$ The Reconciliation Barometer of 2011 indicates that some South Africans feel very confident about the state of reconciliation in South Africa, while others said that 'true reconciliation' was not taking place in South Africa. It indicated further that people chose to associate themselves with people of the same language, ethnicity, and interests, which can be

41 Two group session interviews were held with 16 respondents on 17 October 2012 in Bloemfontein. 
seen as an obstacle that may prevent future interactions between people from different backgrounds. ${ }^{42}$

All 16 respondents were concerned that it might not be possible for South Africa to be completely reconciled, even within 20 years from now. Respondent 1 said that crime and corruption must first be eradicated for reconciliation to take place in the future. Respondent 6 added that South Africa is in a downward spiral due to bad management and poor services which will prevent reconciliation in the future. According to respondents 2, 4 and 9, South Africa has not improved that much for racism to stop within 20 years. Respondent 16 also expressed:

Hopefully in 20 years people will have better relationships with one another and all inequalities will be eradicated, but it is uncertain if this can actually occur. I don't think this is possible. ${ }^{43}$

\section{Evaluation}

With reference to the outcomes and results of the questionnaires one must bear in mind that close to $70 \%$ of the students who completed the questionnaires were Black students with another close to $10 \%$ Coloured students and an Indian student. Thus, without emphasising the race issue, this aspect cannot be ignored in the study and is significant for interpreting the results as more than $75 \%$ of the outcomes are based on what the non-white population groups know of the TRC and think of reconciliation in South Africa in general. Taking gender differences into account in the results, they did not differ significantly. However, it seems that the women appear to be more positive about reconciliation in the country than the males.

Leon Wessels emphasises that it is commonly known that South Africans do not know their history before and during apartheid. ${ }^{44}$ Even the history after apartheid is not that well-known. This is clearly the case with the history students at the UFS main campus. Students had minimal knowledge and few observations about the South African Truth and Reconciliation Commission and what reconciliation entails. The history lecturers at this tertiary institution cannot take it for granted that the contemporary nature of an historical event, which more specifically deals with South African history, or a concept used frequently in the institution and country, is in fact general knowledge for the students. It will be a risk for the lecturer to assume that the average history student has a conceptual understanding of contemporary historical events. It seems as if the average student tends to focus on the content of the modules offered, make use of rote learning and memorise the relevant historical facts and details presented within the modules. If the historical event and accompanying information lies outside the confines of the module content and/or curricula, it appears that the majority of history students at the UFS are uninformed beyond the scope of these presented modules and accompanying information on historical events. The fact the UFS Department of History deals only with the TRC as an historical event on a postgraduate level as part of the curricula and not in detail on undergraduate level, supports this line of argument.

$42 \quad$ Lefko-Everett et al., SA reconciliation barometer survey ..., p. 41.

43 Two group session interviews were held with 16 respondents on 17 October 2012 in Bloemfontein. 
Furthermore, it appears that apart from not being truly well-informed, the TRC and reconciliation as such is not a greatly debated issue among the undergraduate history students at the UFS main campus. It is unfortunate that the average history student is oblivious to the TRC, as it reveals important information about South Africa's past.

It is disturbing that the students so often chose the option 'neutral' in the questionnaire. It can be debated that they did not have an opinion due to a lack of knowledge, and/or to avoid showing their real feelings or opinions about these specific issues. Taking into account their minimum knowledge of the TRC, the neutral option then seems to be the safer option to go with. Nonetheless, it remains surprising that the students do not have more informed and opinionated information on an issue such as reconciliation against the background of all the talk, lectures, development and so on, on the UFS campus regarding reconciliation.

The Reconciliation Barometer of 2011 reveals that South Africans do not know what reconciliation is and how it impacts their lives. ${ }^{45}$ This is in line with the answers given by the students; especially amongst the majority of White students who admitted that reconciliation is never discussed with their friends.

It is important to note that this research focuses on the students' perceptions and knowledge about the TRC and the concept of reconciliation in the country. Therefore, it was not the aim of this particular study to do in-depth research to assess why certain opinions and views were given. To provide answers to the why of the outcomes, could provide additional information to future researchers.

It seems that South Africa still remains a deeply divided country and a more united South Africa where differences are celebrated and not just tolerated, must still emerge. It is important to remember, as previously stated, that reconciliation cannot be forced on or implemented by a person, organisation or institution; it can only systematically take place within a person over time and should be a constant process, continuous through all generations. Therefore, it remains necessary for South Africans to know their past and frequently talk to one another about past events and the future, so that the people of this country can understand one another better and make concerted efforts to reconcile a divided country. 